\title{
A hypophysis adenilát-cikláz aktiváló polipeptid (PACAP) hatása a kardiovaszkuláris rendszerre
}

\author{
Szabó Dóra',3, Szántó Zalán', Jüngling Adél ${ }^{3}$, Polgár Beáta ${ }^{4}$, Reglődi Dóra ${ }^{3}$, \\ Cziráki Attila ${ }^{1}$, Tamás Andrea ${ }^{3 *}$, Sárszegi Zsolt ${ }^{1 *}$
}

${ }^{1}$ Pécsi Tudományegyetem Klinikai Központ, ${ }^{1}$ Szívgyógyászati Klinika, ${ }^{2}$ Sebészeti Klinika,

Pécsi Tudományegyetem Általános Orvostudományi Kar, ${ }^{3}$ Anatómiai Intézet, MTA-PTE PACAP Munkacsoport,

${ }^{4}$ Orvosi Mikrobiológiai és Immunntástani Intézet, Pécs

Levelezési cím:

Dr. Szabó Dóra, e-mail: dora0szabo@gmail.com

\begin{abstract}
A hypophysis adenilát-cikláz aktiváló polipeptid (PACAP) egy multifunkcionális peptid, amelynek neuroprotektív, antiapoptotikus, antioxidáns, citoprotektív és kardioprotektív hatása van. Ismert, hogy a PACAP kardiovaszkuláris rendszerre kifejtett hatásának közvetlen mediálásában a PACAP-receptoroknak van kiemelt szerepe. Az elmúlt évek kutatásai sikeresen azonosították a PAC1-receptor jelenlétét cardiomyocyta sejtkultúrákban és a szívizomzatban, továbbá igazolták a receptor mRNS-ének expresszióját egér szívizomszövetben. Kutatócsoportunk humán jobb pitvari fülcsében mutatta ki a PAC1-receptor jelenlétét immunhisztokémiai módszerrel. In vitro és in vivo funkcionális tesztekben bizonyították a PACAP iszkémiás károsodással szembeni védőhatását; az oxidatív stressz-indukálta károsodásokra fókuszáló vizsgálatokban pedig mind az endogén PACAP-termelés, mind az exogén PACAP-kezelés apoptózist gátló, kardioprotektív hatását igazolták. Munkacsoportunk legutóbbi vizsgálata során arra kereste a választ, hogy a PACAP miként befolyásolja a humán kardiovaszkuláris kórképek lefolyását. Kutatásunkban iszkémiás szívbetegeknél magasabb plazma PACAP-szintet detektáltunk a billentyűbetegekhez képest. Szívelégtelenségben szenvedő iszkémiás és primer dilatatív cardiomyopathiás (DCM) betegek plazma PACAP-szintjének vizsgálatakor jelentős különbségeket találtunk az iszkémiás és nem iszkémiás szívelégtelenek között. Az iszkémiás DCM súlyossága és a plazma PACAP-szintek közötti szignifikáns negatív kapcsolat alapján feltételezhető, hogy a PACAP fontos szerepet tölt be a betegség patomechanizmusában és progressziójában, így a jövőben potenciális kardiológiai biomarkerré is válhat.
\end{abstract}

Kulcsszavak: PACAP, szívelégtelenség, DCM, apoptózis, iszkémia

Effects of pituitary adenylate cyclase activating polypeptide (PACAP) on the cardiovascular system

Pituitary adenylate cyclase activating polypeptide (PACAP) is a multifunctional peptide having neuroprotective, antiapoptotic, antioxidant, cytoprotective and cardioprotective effects. It is well known that PACAP has a direct influence on the cardiovascular system and its effects are mediated by their receptors. Latest studies have successfully shown the presence of PAC1 receptor in cardiomyocyte cell cultures and in heart muscle sections, furthermore, the expression of its mRNA was also detected in mouse heart tissue samples. Moreover, the PAC1 receptor was also identified by our research group in human right atrium with immunohistochemistry. Different in vitro and in vivo functional researches confirmed the protective effects of PACAP against ischemic events. The studies focusing on the oxidative stress-induced damages verified the cardioprotective theory and showed that both endogenous PACAP production and exogenous PACAP treatment leaded to decreased apoptosis of heart muscle cells. The aim of our recent studies was to examine the influence of PACAP on the progression of human cardiovascular diseases. We found significantly higher PACAP levels in heart tissue samples of patients with ischemic heart disorder compared to valvular abnormalities. Remarkable differences were detected between the plasma PACAP levels in ischemic and primary dilated cardiomyopathy. Our study group observed significant negative correlation between the severity of ischemic heart failure and the plasma PACAP levels suggesting that PACAP might play an important role in the pathomechanism and progression of ischemic heart failure and it might be a potential biomarker of cardiac diseases in the future.

Keywords: PACAP, heart failure, DCM, apoptosis, ischemia

*Mindkét szerző egyenlő mértékben járult hozzá a munkához. 
A hypophysis adenilát-cikláz aktiváló polipeptid (PACAP) egy mulitfunkcionális neuropeptid, amelyet 1989-ben birka hypothalamusból izolálták a hypophysisben kifejtett adenilát-cikláz aktiváló hatása alapján (1). A vazoaktív intesztinális peptid (VIP) (szekretin) glukagon peptidcsalád tagja, két aktív formája ismert, egy 27 (PACAP-27), és egy 38 (PACAP-38) aminosavból felépülő izoforma, amelyek 10-90\%-os arányban fordulnak elő. Három különböző receptora ismert, a specifikus PAC1-receptor valamint a VIP-pel közös VPAC1-, és VPAC2-receptorok (2). Számos hatást képes kifejteni, mint a vazodilatátor, antiapoptotikus, antioxidáns és gyulladáscsökkentő hatásai, és ezeken keresztül kifejtett neuroprotektív, neurotrofikus, általános citoprotektív, anyagcserét és az endokrin rendszert befolyásoló hatásokat. A PACAP legnagyobb koncentrációban az idegrendszerben és az endokrin mirigyekben fordul elő, így elsőként neuroprotektív, neurotrofikus és az endokrin rendszerre kifejtett hatásait vizsgálták, azonban később számos más területen is indultak kutatások (3).

\section{PACAP receptor expresszió vizsgálata a kardiovaszkuláris rendszerben}

Az a megfigyelés, hogy direkt PACAP-infúzió tachycardizáló hatással bír felvetette a kérdést, hogy képes-e a PACAP közvetlen hatást kifejteni a kardiovaszkuláris rendszerre (4). Cardiomyocyta sejtkultúrában domináns PAC1-receptor expressziót mutattak ki (5). Továbbá számos állatkísérlet vizsgálta a PACAP és receptorainak jelenlétét a szívizomzatban. Tengerimalacban kimutatták a PACAP szelektív PAC1-receptorokat az intrakardiális neuronokban, később pedig izolált cardiomyocytákban is (6). Egér myocardiumban a PAC1-receptor molekuláris variánsait kutatták, valamint izolált egér pitvarban igazolták a PAC1-receptor jelenlétét, és vizsgálták receptor-mediálta hatásait $(7,8)$. További patkányvizsgálatok igazolták, hogy a PACAP-receptorok nemcsak a pitvarban, hanem kamrai szívizomzatban is jelen vannak (9). Hoover és munkatársai kimutatták a PAC1-receptor mRNS-ét egér szívből, továbbá nem találtak szignifikáns különbséget a receptor expresszióban a pitvari vagy kamrai, illetve bal vagy jobb szívfélből származó minták között. Ugyanezen vizsgálat bizonyította, hogy a receptorok expressziója független a nyomásviszonyok változásától (8). Bár az előbb említett állatkísérletek eredményei támogatták azt a feltételezést, miszerint a PACAP képes közvetlen hatást kifejteni a kardiovaszkuláris rendszerre, azonban napjainkban csak nagyon kevés humán adat áll a rendelkezésünkre a PACAP direkt kardiális hatásait illetően. Elsőként izolált humán miokardiális trabekulákból sikerült kimutatni mindhárom PACAP-receptor mRNS-ét. Nemcsak pitvari, hanem bal kamrából származó mintákat is vizsgáltak, és mindkét esetben jelentős receptor-specifikus mRNS-expressziót detektáltak (10). Molekuláris bizonyítékkal rendelkeztünk már arról, hogy a cardiomyocyták expresszálják a PACAP-receptorokat, azonban pontos elhelyezkedésükről keveset tudtunk. A PAC1-receptor pontosabb feltérképezésére kutatócsoportunk iszkémiás szívbetegség vagy billentyübetegség miatt extracorporalis keringéses szívmütétre kerülő betegek szívizommintáját vizsgálta. A mintákból, amelyek a szív-tüdő motor kanülálásának megfelelően a jobb pitvari fülcséből származtak, hematoxilin-eozin festett metszeteket készítettünk, továbbá ezekkel paralel metszetekből PAC1-receptor immunhisztokémiát végeztünk. Míg az immunfluoreszcens jelölés kimutatta a PAC1-receptor jelenlétét a szívizomsejteken, az endokardiális kötőszövetben nem találtunk PAC1-receptor expressziót (11). Mindezen eredmények igazolták, hogy a cardiomyocyták jelentős PAC1-receptor expressziót mutatnak, amely receptorokat a szívizomzatot innerváló idegvégződésekből felszabadult vagy az extrinsic forrásokból származó keringésben cirkuláló PACAP képes aktiválni (8). Farmakológiai és mRNS-vizsgálatokkal is detektálták a PACAP-receptorok jelenlétét patkányok meningeális és cerebrális artériáiban egyaránt (12). Nemcsak állatkísérletes, hanem humán farmakológiai receptor-karakterizáció is történt, amelynek során meningeális artériákon, továbbá koronáriákon is igazolták a PACAP-receptorok expresszióját (13). A vérben keringő PACAP eredete pontosan nem ismert, azonban legvalószínübb forrásnak az idegrendszert és az endokrin mirigyeket tekinthetjük, ahol a legmagasabb koncentrációban mutatták ki a PACAP jelenlétét (14).

\section{Rövidítésék}

$\mathrm{Bad}=\mathrm{Bcl}-2$ család tagja - apoptózis regulátor (Bcl-2-associated death promoter); $\mathrm{Bax}=\mathrm{Bcl}-2$ család tagja $-\mathrm{X}$-protein; $\mathrm{Bcl}-2$ = B-cell lymphoma 2 - apoptózis regulátor; $\mathrm{Bcl}-\mathrm{xL}=\mathrm{B}$-cell lymphoma extra large - apoptózis regulátor; $\mathrm{COX}=\mathrm{ciklooxigenáz}$ $\mathrm{DCM}$ = dilatatív cardiomyopathia; $\mathrm{EF}$ = ejekciós frakció; $\mathrm{HFrEF}$ = csökkent ejekciós frakcióval járó szívelégtelenség; hsCRP = hiperszenzitív C-reaktív protein; JNK = c-Jun N-terminális kináz; LAD = left anterior descending artery - a bal koronária elülső leszálló ága; mRNS: messenger (hírvivő) ribonukleinsav; NT-proBNP = B-típusú nátriuretikus peptid N-terminális prohormonja; NYHA-stádiumok = New York Heart Association által létrehozott - a szívelégtelenség klinikai tünetek alapján történő súlyossági beosztás: NYHA I.: a fizikai állapot nem korlátozott, NYHA II.: enyhe korlátozottság, fizikai aktivitásra dyspnoe, anginás fájdalom, NYHA III.: jelentős korlátozottság, enyhébb fizikai aktivitás is súlyos tüneteket provokál, de nyugalomban tünetmentes, NYHA IV.: a legkisebb fizikai aktivitás is tünetekkel jár, valamint nyugalomban is jelen vannak, orthopnoe; p38 MAPK = p38 mitogén-aktivált protein-kináz; PACAP = hypophysis adenilát-cikláz aktiváló polipeptid; PACAP-27 = hypophysis adenilát-cikláz aktiváló polipeptid 27 aminosavból felépülő formája; PACAP-38 = hypophysis adenilát-cikláz aktiváló polipeptid 38 aminosavból felépülő formája; PACAP-38-LI = PACAP-38-szerü immunoreaktivitás; PAC1 receptor = PACAP 1. típusú receptora; RIA = radioimmunoassay; ROS = reaktív oxigén szabadgyökök; VIP = vazoaktív intesztinális peptid; VPAC1 receptor= vazoaktív intesztinális peptid receptor1; VPAC2 receptor= vazoaktív intesztinális peptid receptor2 


\section{PACAP hatásai a vaszkuláris rendszerre}

\begin{abstract}
A PACAP potenciálisan vazodilatátor funkcióját többféle állatkísérletes modellen vizsgálták. Tekintettel az idegrendszerben kimutatott magas PACAP-koncentrációra kezdetben a cerebrovaszkuláris rendszer került a kutatások középpontjába. Újszülött sertéseken kimutatták a pia materben futó arteriolák vazodilatációját PACAP-27 és 38 kezelést követően, amely hatást két különböző mechanizmussal képes kifejteni: egy ciklooxigenáz (COX) függő, és egy COX független útvonalon keresztül (15). Emellett patkánymodellben is sikeresen kimutatták a PACAP vazodilatátor funkcióját cerebrális és meningeális artériákon egyaránt $(12,16)$. Így ez a polipeptid neuroprotektív hatását a cerebrovaszkuláris erek tágításán keresztül is képes kifejteni, csökkentve ezzel az esetleges agyi iszkémia súlyos szövődményeit. A PACAP erős vazodilatátor tulajdonsága miatt szerepet játszhat a migrén indukciójában. Szignifikánsan magasabb plazma PACAP-szinteket mértek migrénes egyéneknél az iktális periódusban a rohammentes időszakhoz képest. Továbbá negatív korrelációt találtak a migrénes roham időtartama és a plazma PACAP-koncentráció között (17), valamint migrénes pácienseknél sumatriptan infúziót követően jelentős PACAP-szint csökkenés volt megfigyelhetö $(18,19)$. Mindezek alapján kifejlesztettek egy speciális PAC1-receptor antitestet (AMG 301), mint potenciális migrén ellenes gyógyszer, amelyet jelenleg 2. fázis klinikai vizsgálatokban tanulmányoznak (20).
\end{abstract}

Nemcsak a centrális, hanem a perifériás ereken is vizsgálták a PACAP vazodilatátor effektusát. Kutatócsoportunk korábban patkány carotis és basilaris érpreparátumok vizsgálata alapján megállapította, hogy a PACAP feltehetöleg nagyobb hatással bír a centrális artériákon a perifériásokhoz képest, továbbá ezen vazodilatátor hatása korfüggö és szövetspecifikus (21). Ugyanakkor PACAP-deficiens egerek carotis és femoralis artériájában exogén PACAP és VIP indukálta relaxáció vizsgálatának során a PACAP-deficiens egereknél szignifikánsan nagyobb mértékủ relaxációt detektáltak miográffal a vad típushoz képest. Míg PACAP-antagonista adásakor teljesen megszünt a relaxáció (22). Mindezen eredmények alapján feltételezhető, hogy az általunk vizsgált polipeptid fontos fiziológiai szerepet játszik a vaszkuláris tónus kialakításában.

Mind a centrális, mind a perifériás ereken kifejtett értágító hatás felveti annak lehetőségét, hogy a PACAP esetleg akár a koronáriákon is képes vazodilatátor hatást kifejteni. Ezt a feltevést támasztja alá a PACAP-receptorok jelenléte a koronáriák simaizomzatában (13), valamint az az állatkísérlet, amelynek során újszülött sertésszíveket vizsgálva intravénásan adott PACAP-38 hatására koronária vazodilatációt tapasztaltak (23). Sőt, humán koronária simaizomsejteken is kimutatták a $\mathrm{K}(\mathrm{ATP})$ és $\mathrm{K}(\mathrm{Ca})$ csatornákon keresztül kifejtett PACAP-indukálta vazodilatációt (24).

\section{PACAP hatása az iszkémiás károsodással szemben}

Számos tanulmány vizsgálta már a PACAP kardiovaszkuláris rendszerre kifejtett hatásait, s ezen eredmények bizonyították, hogy a PACAP pozitív chronotrop, inotrop $(4,25)$ és dromotrop hatásokkal bír, potens vazodilatátor (21), továbbá antiapoptotikus és antioxidáns hatásain keresztül a különböző káros effektusokkal szemben (iszkémia, oxidatív stressz) kardioprotektív szerepe van. Kutatócsoportunk izolált cardiomyocyta sejtkultúrán iszkémia/reperfúziós károsodás okozta apoptózissal szembeni PACAP védőhatást mutatott ki. Hatvan perces iszkémia, majd 120 perces reperfúziót követően PACAP-kezelés hatására csökkent sejthalált, fokozott cardiomyocyta túlélést detektáltunk. Mindezen hatását a különböző proapoptotikus faktorok gátlása (Bad, kaszpáz-3), illetve antiapoptotikus utak (Bcl-xL) serkentése révén fejtette ki protektív hatását az általunk vizsgált polipeptid (26). További kutatások a PACAP-kezelés és a prekondicionálás védő hatását vizsgálták iszkémia/reperfúzió-indukálta cardiomyocyta apoptózisban. Mindkét esetben szignifikánsan emelkedett sejttúlélést és jelentős kardioprotektív hatást tapasztaltak, azonban a két módszer hatása nem bizonyult additívnak (27). Továbbá Alston és munkatársai iszkémia/reperfúzió modellben szignifikánsan magasabb PACAP-értékeket, illetve magasabb PACAP mRNS-expressziót detektáltak egerek LAD-ligatúrával létrehozott mesterséges akut miokardiális infarktusa után. Valamint immunhisztokémiai módszerekkel kimutatták a PACAP-38 immunreaktivitás lokalizációját a károsodott szívizomzatban, amely pontosan megfelelt az infarktusos területnek. Mindezen eredmények arra utalnak, hogy a PACAP fontos szerepet tölthet be a kardiális és neuronális remodellingben ischaemia/reperfúziós károsodást követően (28). Az in vitro és állatkísérletes eredmények alapján - amelyek a PACAP iszkémiás károsodásokkal szemben kifejtett kardioprotektív hatását igazolták - felmerül a kérdés, hogy milyen szerepe lehet az általunk vizsgálat neuropeptidnek a humán kardiovaszkuláris kórképekben (1. ábra). Kutatócsoportunk humán pitvari fülcséből származó mintákban szignifikánsan magasabb PACAP-38 és PACAP-27 szinteket detektált az iszkémiás szívbetegeknél a billentyübetegekhez képest (11), amely eredmények szintén alátámasztják a PACAP iszkémiás károsodással szemben kifejtett védőhatásának elméletét (1., 2. ábra). Tekintettel arra, hogy mintáink a jobb pitvari fülcséböl származtak, olyan betegeket válogattunk be vizsgálatunkba, akik ismert pitvari patológiával (pl. pitvarfibrilláció) nem rendelkeztek, ezzel is kizárva az esetleges befolyásoló tényezőket. Számos állatkísérlet bizonyította, hogy a PAC1-receptor expressziója független a szívüregekben mérhető nyomásviszonyoktól, továbbá a pitvarok és kamrák és a jobb - bal szívfél között sem találtak érdemi különbséget $(8,9)$. Így fel- 


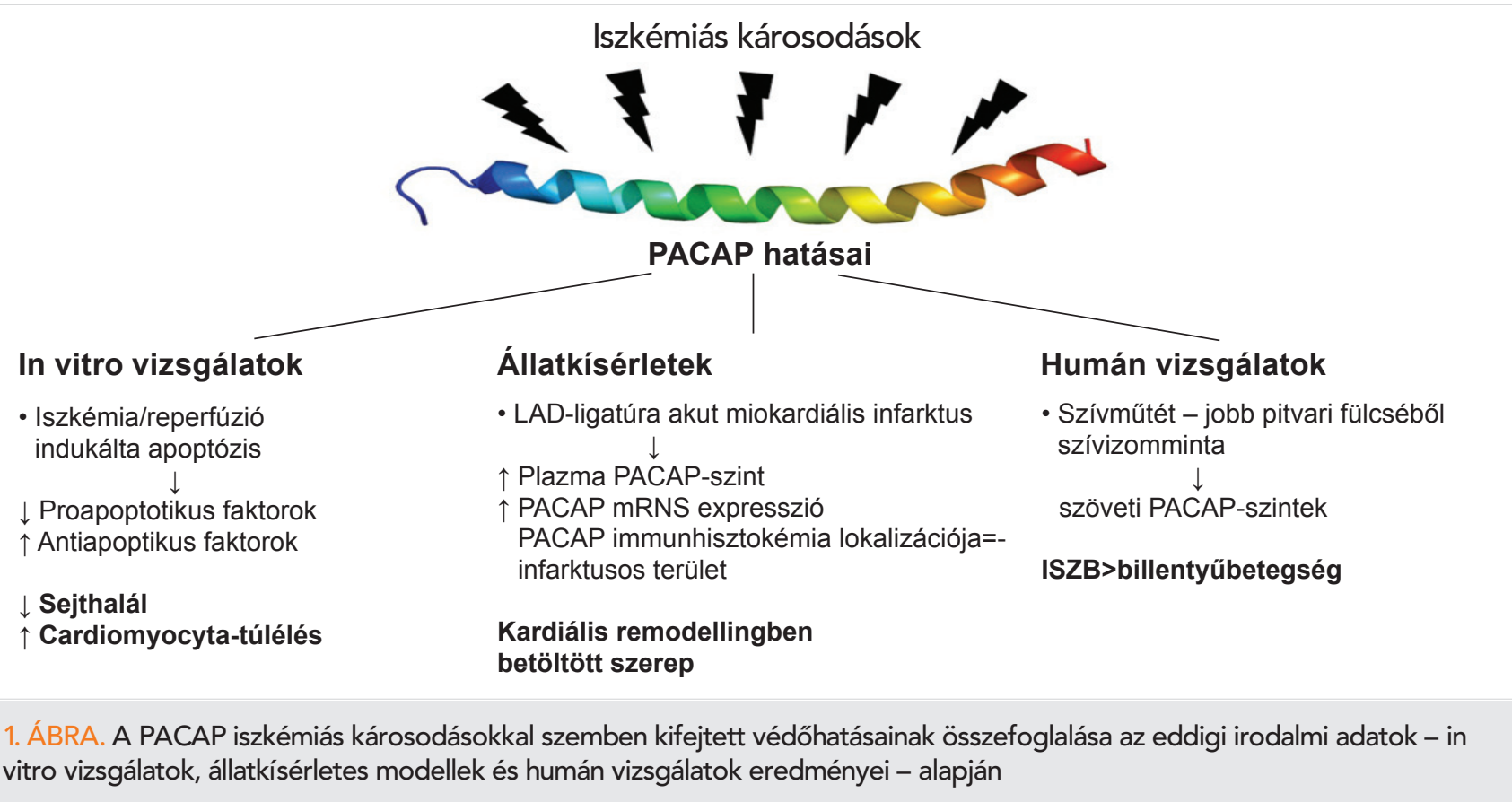

vitro vizsgálatok, állatkísérletes modellek és humán vizsgálatok eredményei - alapján

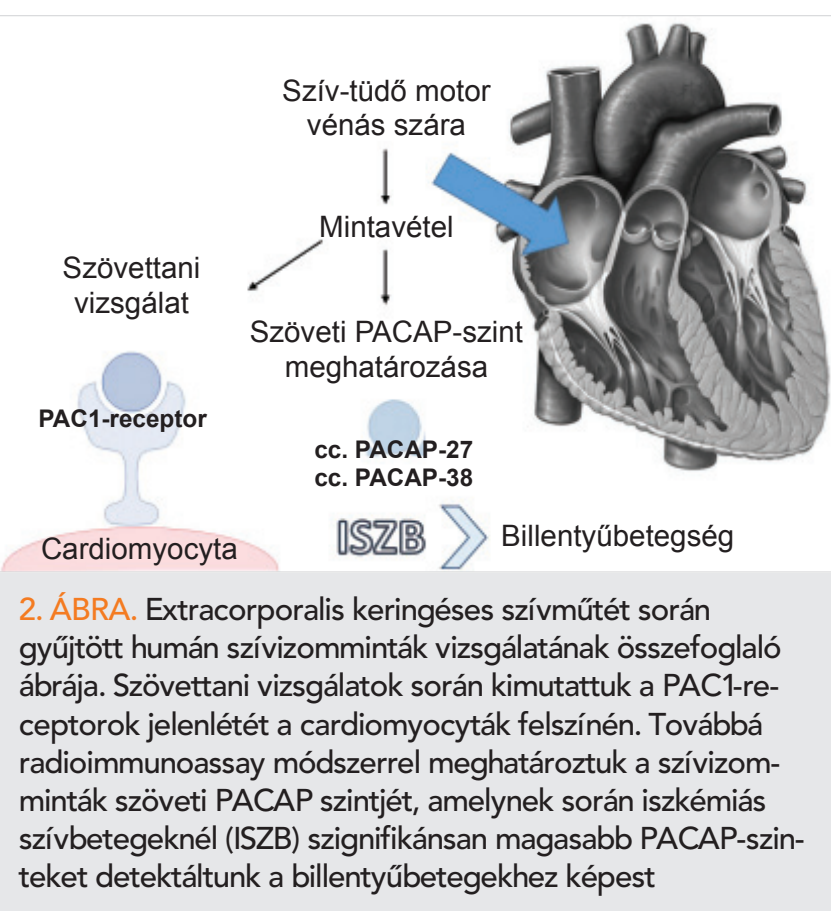

tételezhető, hogy a szöveti PACAP-szinteket sem befolyásolják ezen tényezők, ugyan erre konkrét bizonyítékunk nincs.

\section{PACAP kardioprotektív hatása szívelégtelenségben}

A PACAP kardioprotektív hatását elöször Sano és munkatársai 2002-ben vetették fel, amikor igazolták, hogy a PACAP fibroblasztokban szelektíven gátolja a DNS és protein szintézisét, és ezáltal csökkenti a mi- okardiális fibrózist, ugyanakkor miokardiális sejteken ilyen hatást nem fejt ki (5). Korábbi tanulmányok eredményei alapján feltételezhető, hogy a PACAP elsősorban olyan kardiovaszkuláris kórképek progressziójára képes hatást kifejteni, amelyek kialakulásában az oxidatív stressz és az apoptózis fontos szerepet játszik, mint pl. a szívelégtelenség vagy az iszkémiás szívbetegség (3). Irodalmi adatok szerint a PACAP-38 effektíven védi a cardiomyocytákat az oxidatív stressz által okozott apoptózistól. Ezen hatását izolált sejtkultúrán bizonyították, ahol PACAP-kezelés hatására szignifikánsan alacsonyabb kaszpáz-3 aktivitás, valamint szignifikánsan magasabb antiapoptotikus $\mathrm{Bcl}-2$ és foszfo-Bad expresszió volt megfigyelhető $(29,30)$. Ugyanezt az antiapoptotikus hatást endotheliális sejteken is kimutatták, ahol PACAP-38 kezelés szignifikánsan csökkentette a proapoptotikus JNK és p38 MAP-kináz aktivitását oxidatív stresszhatásban (31).

A doxorubicin által okozott kardiotoxicitás patofiziológiai alapja a mitokondriális antiapoptotikus útvonalak szuppressziója és a proapoptotikus bax és kaszpáz-3 útvonalak fokozott expressziója (32). A szívizomsejteken megtalálható PAC1-receptoron keresztül PACAP hatására a Bax és kaszpáz-3 útvonalak inaktivációja következik be, amely végső soron kardioprotektív hatást eredményez a doxorubicin kardiotoxikus hatásával szemben.

A szívelégtelenség egyik klasszikus állatkísérletes modelljében, doxorubicinnel indukált cardiomyopathiában vizsgálták a PACAP hatását a betegség progressziójára. PACAP-deficiens (heterozigóta és homozigóta) egerekben a doxorubicin által indukált szívelégtelenség súlyosabb lefolyású volt, mint a vad típusban. A PACAP-deficiens egereknél echokardiográfiával sokkal súlyosabb balkamra-dilatáció és szignifikánsan alacso- 


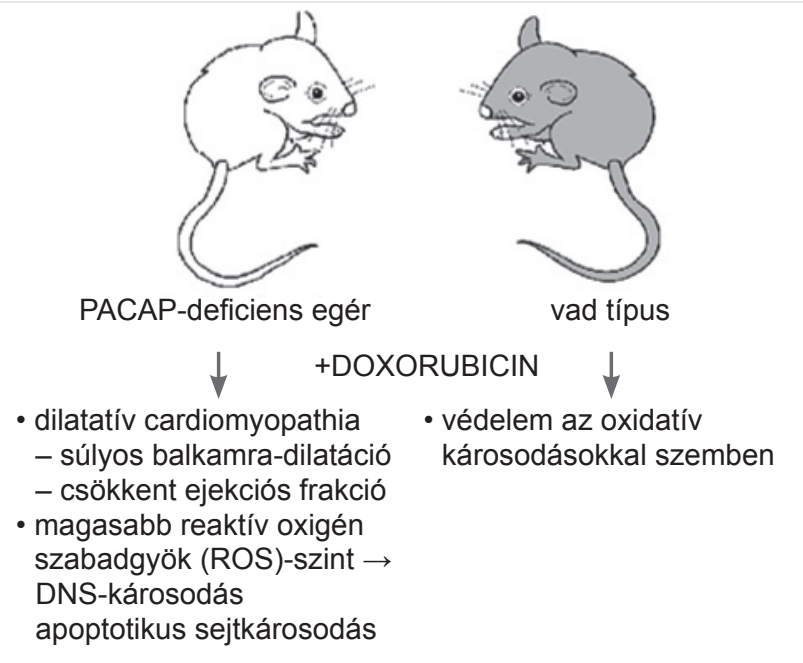

3. ÁBRA. A szívelégtelenség egyik klasszikus állatkísérletes modellje, amelyben doxorubicinnel indukált cardiomyopathiaban igazolták a PACAP kardioprotektív hatását

nyabb szisztolés balkamra-funkció ábrázolódott, valamint mortalitásuk is jelentősen magasabbnak bizonyult a vad egerekhez képest. PACAP hiányában szignifikánsan magasabb - a patofiziológiai folyamatban jelentős szerepet játszó - reaktív oxigéngyök-szinteket, s ennek következtében sokkal súlyosabb DNS-károsodást, illetve apoptotikus sejtkárosodást detektáltak a vad típusú egerekhez képest. Ezek alapján feltételezhető, hogy az endogén PACAP-nak kardioprotektív hatása van a doxorubicin indukálta szívelégtelenségben. Ugyanebben a modellben intraperitoneálisan adott exogén PACAP a heterozigóta PACAP-deficiens egerekben csökkentette az elektronmikroszkóppal kimutatható miofibrilláris károsodást a placebo kezeléshez képest, bár az oxidatív stressz és túlélés tekintetében nem eredményezett szignifikáns javulást (32) (3. ábra). Egy hasonló citosztatikummal végzett másik vizsgálatban igazolták, hogy a PACAP véd a mitoxandron kardiotoxikus hatásával szemben (33). Otto és munkatársai PAC1-receptor-deficiens egerekben pulmonalis hipertóniát és jobb szívfél elégtelenséget találtak (34).

$A z$ in vitro és állatkísérletes eredmények alapján amelyek a PACAP kardioprotektív hatását igazolták felmerül a kérdés, hogy milyen szerepe lehet az endogén PACAP-nak a humán kardiovaszkuláris kórképek lefolyásában? Az alapkutatási eredmények alapján kutatócsoportunk szívelégtelen betegek vizsgálata során kereste a választ arra a kérdésre, hogy vajon a szívelégtelenség súlyosságát jelző paraméterek és az endogén PACAP mennyisége között található-e ok-okozati összefüggés; a magasabb szérum PACAP-szint lehet-e prediktora a jobb prognózisnak?

A csökkent szisztolés balkamra-funkcióval járó szívelégtelenség (HFrEF) progressziójának becslésére a klinikai gyakorlatban az echokardiográfia, a szív MR-vizsgálat és különböző biomarkerek állnak rendel- kezésünkre. Számos biomarkert vizsgáltak már a szívelégtelenséggel kapcsolatban, mint a magas szenzitivitású C-reaktív protein (hs-CRP), troponin-T és a kreatinin-kináz (35). Legmegbízhatóbb markernek azonban a B-típusú nátriuretikus peptid N-terminális prohormonja (NT-proBNP) bizonyult, habár ennek a vizsgálómódszernek is vannak limitációi, különösen nem akut esetekben (36). A klinikai tapasztalat azt mutatja, hogy hasonló NT-proBNP-szinttel rendelkező szívelégtelen betegek ugyanarra a gyógyszeres terápiára különbözőképpen reagálnak. Ennek hátterében nyilvánvalóan az áll, hogy számos faktor befolyásolja a betegség progresszióját. Az eddigi PACAP-pal kapcsolatos kutatási eredmények alapján feltételezhető, hogy a PACAP hatással van a szívelégtelenség prognózisára. Ennek a kérdésnek a tisztázására megvizsgáltuk, hogy a plazma PACAP-szintek, NT-proBNP-szintek, illetve a szisztolés balkamra-funkció mutatnak-e összefüggést szívelégtelenségben. Vizsgálatunkban a csökkent szisztolés balkamra-funkcióval járó szívelégtelenség (HF-rEF) két jól definiált, gyakori formáját, a primer és az iszkémiás dilatatív cardiomyopathiás (DCM) betegcsoportot választottuk, amely betegség etiológiai tényezői között az apoptózis fontos szerepet játszik.

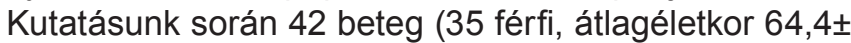
5,66 év) perifériás vénás vérmintáját vizsgáltuk, akik primer $(n=9)$ vagy iszkémiás $(n=33)$ dilatatív cardiomyopathia miatt álltak gondozásunk alatt. Betegeinket szisztolés balkamra-funkciójuk alapján válogattuk be vizsgálatunkba $(E F<40 \%)$, amelyet Simpson-módszerrel (37) határoztuk meg. Pácienseink 73,4\%-a hipertónia, 40,5\%-a diabetes mellitus miatt állt kezelés alatt. Korrelációs analízis nem mutatott szignifikáns összefüggést a PACAP-szintek valamint a nem, kor, hipertónia, diabetes mellitus és számos rutin laboratóriumi paraméter között. Tehát a korábbi irodalmi adatoknak megfelelően mi is bizonyítottuk, hogy ezen tényezők nincsenek befolyással a PACAP-szintekre (4). A plazma PACAP-38-szerü immunoreaktivitás (PACAP-38-LI) meghatározása radioimmunoassay (RIA) módszerrel történt. Az iszkémiás DCM-csoportba tartozó betegeket további három alcsoportra bontottuk a szívelégtelenség súlyosságának megfelelően, a klinikai tünetek és a plazma NT-proBNP-szintek alapján. Így elkülönítettünk egy enyhe $(n=6, N T-p r o B N P<500$ pg/ml, I. fokú a New York-i Társaság [NYHA I-II.] funkcionális klasszifikációja alapján), egy közepesen súlyos ( $n=16$, NT-proB$\mathrm{NP}=500-3000 \mathrm{pg} / \mathrm{ml}$, NYHA III.) és egy súlyos $(n=11$, NT-proBNP>3000 pg/ml, NYHA IV.) szívelégtelen csoportot. A NYHA klasszifikációt a tünetek súlyosságának megítélésére használtuk. Bár a legújabb kutatások azt mutatják, hogy a tünetek súlyossága kevéssé korrelál a szisztolés balkamra-funkcióval, azonban egyértelmü kapcsolat látható a tünetek súlyossága és a túlélés, valamint a hospitalizáció gyakorisága között $(35,38)$. A primer DCM-csoportban a PACAP-38-LI és NT-proBNP plazmaszintek között nem találtunk korrelációt. 


\begin{tabular}{|c|c|c|c|c|}
\hline & Dila & jopathia (DCM) & & \\
\hline & Primer DCM & Iszkémiás DCM & & \\
\hline - PACAP-NT-proBNP & Nincs összefüggés & $\begin{array}{l}\text { 1. enyhe HF } \\
\text { 2. közepesen súlyos HF } \\
\text { 3. súlyos HF }\end{array}$ & $\begin{array}{l}\text { erős } \\
\text { kp. erős } \\
\text { gyenge }\end{array}$ & $\begin{array}{l}\text { negatív } \\
\text { korreláció }\end{array}$ \\
\hline - NT-proBNP - EF & Negatív korreláció & Negatív korreláció & & \\
\hline - PACAP - EF & Nincs összefüggés & Pozitív tendencia & & \\
\hline
\end{tabular}

4. ÁBRA. Szívelégtelenség (HF) - dilatatív cardiomyopathia miatt gondozásunk alatt álló betegek vizsgálatának során detektált plazma PACAP-, NT-proBNP-szintek és ejekciós frakciós (EF) értékek közötti összefüggések összefoglaló táblázata

Ezzel szemben szignifikáns negatív korrelációt detektáltunk a plazma PACAP-38-LI és NT-proBNP-szintek között az iszkémiás betegcsoportban. Enyhe és közepesen súlyos szívelégtelen csoportunkban erős, illetve közepesen erős szignifikáns negatív korrelációt találtunk a két vizsgált faktor között. A harmadik csoportba tartozó súlyos szívelégtelenségben szenvedő betegeinknél valamivel gyengébb negatív korreláció volt. Az ejekciós frakció és NT-proBNP-értékek között mindkét betegcsoportban szignifikáns negatív korrelációt találtunk, a két alcsoport között érdemi különbség nem volt. Ezzel szemben a plazma PACAP-38-LI-szintek és EF kapcsolatának vizsgálatakor jelentős eltérést detektáltunk a két különböző etiológiájú szívelégtelen csoport között. Míg a primer DCM-es betegcsoportban nem találtunk összefüggést a két vizsgált paraméter között, addig az iszkémiás DCM-csoportban pozitív tendencia, egy gyenge pozitív korreláció volt a PACAP-szintek és az EF között (39) (4. ábra). Ez a megfigyelés is alátámasztja a PACAP jelentős iszkémiás károsodással szemben kifejtett védő hatásának szerepét.

\section{Következtetések}

Összefoglalva, vizsgálatunkban bebizonyítottuk, hogy a plazma PACAP-szintek szignifikánsan változnak szívelégtelenségben, továbbá összefüggést mutatnak az NT-proBNP-szintekkel és az ejekciós frakcióval.

A szívelégtelenség és a magasabb plazma PACAPszintek közötti ok-okozati összefüggés további vizsgálata feltétlenül szükséges. Nem tisztázott, hogy a szívelégtelenség kialakulása, különösen iszkémiás szívbetegség talaján, milyen szignál útján vált ki a központi idegrendszerben vagy az endokrin rendszerben a fokozott PACAP-termelést? Egy további tisztázandó kérdés, hogy ez az emelkedett endogén PACAP-szint gyakorol-e védő hatást a még életképes szívizomsejtekre, és vajon lassítja-e a szívelégtelenség progreszszióját? Jövőbeni célunk az általunk vizsgált betegpopuláció kibővítése, hosszú távú követéses vizsgálat elvégzése repetitív plazma PACAP-szint meghatározásokkal, és ezek alapján lenne megválaszolható a kérdés, hogy lehet-e a plazma PACAP-szint a szívelég- telenség progressziójának prediktora. Végül az sem tisztázott, hogy az endogén PACAP-termelés vajon fokozható-e valamilyen módon vagy exogén PACAP-bevitellel lassítható-e a szívelégtelenség progressziója és védhető-e a szívizomzat az iszkémiás károsodásokkal szemben?

\section{Támogatások}

NKFIH K119759; GINOP-2.3.2-15-2016-00050 „Pepsys"; EFOP-3.6.1.-16-2016-00004; TAMOP 4.2.4.A/211- 1-2012- 0001 Nemzeti Kiválóság Program; UNKP. 16-4-IV Új Nemzeti Kiválóság Program; MTA TKI 14016 Program; Bolyai Ösztöndij; EFOP-3.6.2-162017-00009.

\section{Irodalom}

1. Miyata A, Arimura A, Dahl RR, et al. Isolation of a novel 38 residue-hypothalamic polypeptide which stimulates adenylate cyclase in pituitary cells. Biochem Biophys Res Commun 1989; 164(1): 567-74. doi: 10.1016/0006-291X(89)91757-9

2. Vaudry D, Falluel-Morel A, Bourgault S, et al. Pituitary adenylate cyclase-activating polypeptide and its receptors: 20 years after the discovery. Pharmacol Rev 2009; 61(3): 283-357. doi: 10.1124/ pr.109.001370

3. Reglodi D, Tamas A. Pituitary adenylate cyclase activating polypeptide - PACAP. 1st ed. Switzerland: Springer; 2016.

4. Farnham MM, Inglott MA, Pilowsky PM. Intrathecal PACAP-38 causes increases in sympathetic nerve activity and heart rate but not blood pressure in the spontaneously hypertensive rat. Am J Physiol Heart Circ Physiol 2011; 300(1): 214-22. doi: 10.1152/ajpheart.00662.2010

5. Sano H, Miyata A, Horio T, et al. The effect of pituitary adenylate cyclase activating polypeptide on cultured rat cardiocytes as a cardioprotective factor. Regul Pept 2002; 109(1-3): 107-13. doi: 10.1016/S0167-0115(02)00193-3

6. Chang Y, Lawson LJ, Hancock JC, et al. Pituitary adenylate cyclase-activating polypeptide: localization and differential influence on isolated hearts from rats and guinea pigs. Regul Pept 2005; 129(13): 139-46. doi: 10.1016/j.regpep. 2005.02.012

7. Ushiyama M, Sugawara H, Inoue K, et al. Characterization of the PAC1 variants expressed in the mouse heart. Ann N Y Acad Sci 2006; 1070: 586-90.

8. Hoover DB, Girard BM, Hoover JL, et al. PAC1 receptors mediate positive chronotropic responses to PACAP-27 and VIP in isolated mouse atria. Eur J Pharmacol 2013; 713(1-3): 25-30. doi: 10.1016/j. ejphar.2013.04.037

9. Wei Y, Mojsov S. Multiple human receptors for pituitary adenylyl cyclase-activating polypeptide and vasoactive intestinal peptide are 
expressed in a tissue-specific manner. Ann N Y Acad Sci 1996; 805: 624-7. doi: 10.1111/j.1749-6632.1996.tb17531.x

10. Saetrum O, Knutsson M, De Vries R, et al. Vasoactive intestinal peptide has a direct positive inotropic effect on isolated human myocardial trabeculae. Clinical Science 2001; 101(6): 637-43. doi: $10.1042 /$ cs 1010637

11. Szanto Z, Sarszegi Z, Reglodi D, et al. PACAP immunoreactivity in human malignant tumor samples and cardiac diseases. J Mol Neurosci 2012; 48(3): 667-73. doi: 10.1007/s12031-012-9815-4

12. Boni LJ, Ploug KB, Olesen J, et al. The in vivo effect of VIP, PACAP-38 and PACAP-27and mRNA expression of their receptors in rat middle meningeal artery. Cephalalgia 2009; 29(8): 837-47. doi: 10.1111/j.1468-2982.2008.01807.x

13. Chan KY, Baun M, de Vries $R$, et al. Pharmacological characterization of VIP and PACAP receptors in the human meningeal and coronary artery. Cephalalgia 2011; 31(2): 181-9. doi: $10.1177 / 0333102410375624$

14. Reglodi D, Helyes Zs, Nemeth J, et al. PACAP as a potential biomarker - alterations of PACAP levels in human physiological and pathological conditions. In: Reglodi D, Tamas A, editors. Pituitary adenylate cyclase activating polypeptide - PACAP, 1st ed. Switzerland: Springer; 2016. pp. 815-32. doi: 10.1007/978-3-319-35135-3_48

15. Lenti L, Domoki F, Kis D, et al. Pituitary adenylate cyclase-activating polypeptide induces pial arteriolar vasodilatation through cyclooxygenase-dependent and independent mechanisms in newborn pigs. Brain Research 2007; 1165: 81-8.

16. Syed AU, Koide M, Braas KM, et al. Pituitary adenylate cyclase-activating polypeptide (PACAP) potently dilates middle meningeal arteries: implications for migraine. J Mol Neurosci 2012; 48(3): 574-83.

17. Tuka B, Helyes Z, Markovics A, et al. Alterations in PACAP38-like immunoreactivity in the plasma during ictal and interictal periods of migraine patients. Cephalgia 2013; 33: 1085-95.

18. Hansen JM, Fahrenkrung J, Petersen J, et al. Vasoactive intestinal peptide (VIP) and pituitary adenylate cyclase activating polypeptide (PACAP) in the circulation after sumatriptan. Scand J Pai 2013; 4: 211-6.

19. Zagami AS, Edvinsson L, Goadshy PJ. Pituitary cyclase activating polypeptide and migraine. Ann Clin Transl Neurol 2014; 1(12): 1036-40.

20. Reglodi D, Vaczy A, Rubio-Beltran E, et al. Protective effects of PACAP in ischemia. J Headache Pain 2018; 19(1): 19.

21. Vamos Z, Ivic I, Cseplo $P$, et al. Pituitary adenylate cyclase-activating polypeptide (PACAP) induces relaxations of peripheral and cerebral arteries, which are differentially impaired by aging. J Mol Neurosci 2014; 54(3): 535-42.

22. Ivic I, Fulop BD, Juhasz $T$, et al. Backup mechanisms maintain PACAP/VIP-induced arterial relaxations in pituitary adenylate cyclase-activating polypeptide-deficient mice. J Vasc Res 2017; 54(3): 180-92.

23. Ascuitto RJ, Ross-Ascuitto NT, Waddell AE, et al. Contractile and coronary vascular effects of pituitary adenylate cyclase activating polypeptide in neonatal pig hearts. Cardiovasc Res 1996; Spec No: E153-9.

24. Bruch I, Bychkov R, Kästner A, et al. Pituitary adenylate-cyclase-activating peptides relax human coronary arteries by activating
$\mathrm{K}(\mathrm{ATP})$ and $\mathrm{K}(\mathrm{Ca})$ channels in smooth muscle cells. J Vasc Res 1997; 34(1): 11-8.

25. Clason TA, Girard BM, May V, et al. Activation of MEK/ERK signaling by PACAP in guinea pig cardiac neurons. J Mol Neurosci 2016; 59(2): 309-16.

26. Racz B, Gasz B, Gallyas F JR, et al. PKA-Bad-14-3-3 and AktBad-14-3-3 signaling pathways are involved in the protective effects of PACAP against ischemia/reperfusion-induced cardiomyocyte apoptosis. Regul Pept 2008; 145(1-3): 105-15.

27. Roth E, Weber G, Kiss P, et al. Effects of PACAP and preconditioning against ischemia/reperfusion-induced cardiomyocyte apoptosis in vitro. Ann N Y Acad Sci 2009; 1163: 512-6.

28. Alston EN, Parrish DC, Hasan W, et al. Cardiac ischemia-reperfusion regulates sympathetic neuropeptide expression through gp130-dependent and independent mechanisms. Neuropeptides 2011; 45(1): 33-42.

29. Gasz B, Racz B, Roth E, et al. Pituitary adenylate cyclase activating polypeptide protects cardiomyocytes against oxidative stress-induced apoptosis. Peptides 2006; 27(1): 87-94.

30. Gasz B, Racz B, Roth E, et al. PACAP inhibits oxidative stress-induced activation of MAP kinase-dependent apoptotic pathway in cultured cardiomyocytes. Ann N Y Acad Sci 2006; 1070: 293-7.

31. Racz B, Gasz B, Borsiczky B, et al. Protective effects of pituitary adenylate cyclase activating polypeptide in endothelial cells against oxidative stress-induced apoptosis. Gen Comp Endocrinol 2007; 153(1-3): 115-23.

32. Mori H, Nakamachi $\mathrm{T}$, Ohtaki $\mathrm{H}$, et al. Cardioprotective effect of endogenous pituitary adenylate cyclase-activating polypeptide on Doxorubicin-induced cardiomyopathy in mice. Circ J 2010; 74(6): 1183-90.

33. Subramaniam V, Chuang G, Xia H, et al. Pituitary adenylate cyclase-activating polypeptide (PACAP) protects against mitoxantrone-induced cardiac injury in mice. Peptides 2017; 95: 25-32.

34. Otto $C$, Hein L, Brede M, et al. Pulmonary hypertension and right heart failure in pituitary adenylate cyclase-activating polypeptide type I receptor-deficient mice. Circulation 2004; 110(20): 3245-51.

35. ESC Guideline for the diagnosis and treatment of acute and chronic heart failure. Heart Journal 2016.

36. Kelder JC, Cramer MJ, Verweij WM, et al. Clinical utility of three B-type natriuretic peptide assays for the initial diagnostic assessment of new slow-onset heart failure. J Card Fail 2011; 17(9): 72934.

37. Dornberger V, Dittrich HD, Busch R. Echocardiographic evaluation of systolic left ventricular function in heart failure: value of alternative parameters for determination of ejection fraction. 2015 Herz 40(2): 185-93.

38. McMurray JJ, Adamopoulos S, Anker SD, et al. ESC Guidelines for the diagnosis and treatment of acute and chronic heart failure 2012: The Task Force for the Diagnosis and Treatment of Acute and Chronic Heart Failure 2012 of the European Society of Cardiology. Developed in collaboration with the Heart Failure Association (HFA) of the ESC. Eur Heart J 2012; 33(14): 1787-847.

39. Sarszegi Z, Szabo D, Gaszner B, et al. Examination of Pituitary Adenylate Cyclase-Activating Polypeptide (PACAP) as a potential biomarker in heart failure patients. J Mol Neurosci 2018. In press. https://doi.org/10.1007/s12031-017-1025-7. 